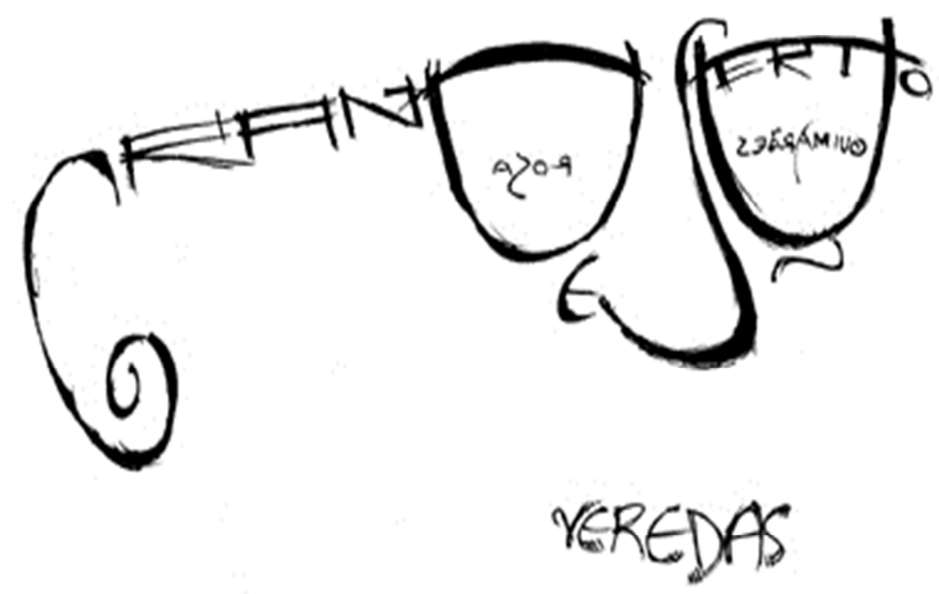

Ricardo D'agostini

\title{
A linguagem oculta de Guimarães Rosa
}

\section{Jorge Fernando dos Santos}

Compositor, escritor e jornalista. Editor de suplementos do jornal Estado de Minas, exerceu anteriormente as funções de repórter, articulista e editor de cultura. Teve várias peças teatrais encenadas, produziu CDs com músicas de sua autoria e publicou 25 livros, dentre eles os romances Palmeira seca (Prêmio Guimarães Rosa), o rei da rua e Sumidouro das almas, os dois primeiros pela Atual Editora e adaptados para TV. Seu conto "Amor estranho" foi transformado num curta-metragem. Publicou pela Paulus a novela No clarão das águas e o $A B C$ da MPB, livro e disco sobre a música popular brasileira, ganhador do selo de "Altamente recomendável" da Fundação Nacional do Livro Infantil e Juvenil (FNLIJ). Em 2006, lançou pela Paulinas a coletânea de haicais Pó de palavra, livro e disco. Seu endereço na internet é www.jorgefernandosantos.com.br 


\section{Resumo}

No romance Grande sertão: veredas, considerado o livro mais importante já publicado no Brasil, o escritor centenário Guimarães Rosa aborda com sutileza e inteligência temas e símbolos relacionados ao conhecimento iniciático universal. Confessadamente um homem místico, o autor nascido em Cordisburgo, Minas Gerais, instiga leitores e pesquisadores a estudarem sua obra não só pelos requintes de linguagem, mas também sob o ponto de vista de várias correntes do pensamento esotérico ou iniciático.

Palavras-chave: Grande sertão: veredas, Guimarães Rosa, pensamento esotérico.

Apontado como o livro mais importante da literatura brasileira, o romance Grande sertão: veredas completou 50 anos de publicação em 2006. No entanto, a mídia nacional, sobretudo televisiva, não soube aproveitar a oportunidade para divulgar e desvendar esse verdadeiro enigma literário da cultura brasileira. Precipitadamente vinculado ao "regionalismo" pelos críticos mais afoitos, o autor hoje centenário, João Guimarães Rosa, não se limitou a reproduzir aspectos meramente locais em sua obra. Pelo contrário, partiu da recriação desses aspectos para narrar epopéias que ultrapassam o universal e atingem 0 campo transcendental. Para ele, "sertão é dentro da gente".

Estudado em vários países devido, principalmente, aos requintes de linguagem de sua literatura, Rosa pode encantar o leitor também sob outros aspectos. Estudiosos de sua obra, leitores comuns e professores que trabalham Grande sertão: veredas em sala de aula devem procurar no texto não apenas as águas da superfície, onde se narra o enredo principal de aventuras, mas também as correntes mais profundas, nas quais habitam senhas e símbolos de diferentes escolas filosóficas e esotéricas. Longe da religiosidade oficial, o autor procurava dar um sentido profundo e oculto a tudo o que escrevia, fazendo de sua literatura um jogo que desafia olhares argutos. Não por coincidência ele foi um aficionado do xadrez e leitor de obras transcendentais relacionadas a outras culturas.

Por essas e outras, os iniciados em Rosa são constantemente convidados (ou mesmo desafiados) a enxergar e a interpretar tais senhas e símbolos sob a luz da Alquimia, da Astrologia, do Hinduísmo, da Maçonaria, do Platonismo, do Taoísmo ou mesmo da Psicanálise. Isso faz de sua obra algo maior do que a literatura, por excelência, repleta de significados e labirintos que the dão abertura para várias interpretações. Há quem considere o Grande sertão: veredas uma espécie de livro sagrado, feito para ser 
"recitado" em voz alta, ritualisticamente, como a Bíblia ou o Bhagavad Gita.

Fanatismos à parte, Rosa não quis nos oferecer uma obra rasa, de fácil leitura e compreensão, destinada ao mero entretenimento, como tantos best-sellers que entopem as livrarias nos dias atuais. Poucos tiveram tanta consciência da escrita quanto ele. A exemplo de autores clássicos como Homero, Dante, Cervantes, Goethe, Dostoiévski, Borges e Fernando Pessoa, para ele a palavra era forma, fôrma e energia. Mais que isso, era um símbolo a transmitir idéias e a despertar o inconsciente do leitor. Sua sabedoria no trato com - vernáculo, principal ferramenta de quem escreve, tornou-se o grande diferencial de sua obra, algo insuperável em comparação com outros escritores. Também o fio da narrativa é inovador, se considerarmos que o "doutor" a quem o protagonista Riobaldo narra sua epopéia é ninguém menos que o próprio autor podendo, em outro momento, ser também o leitor.

Guimarães Rosa era poliglota. Numa entrevista concedida a uma prima, afirmou:

Falo português, alemão, francês, inglês, espanhol, italiano, esperanto, um pouco de russo; leio sueco, holandês, latim e grego (mas com o dicionário agarrado); entendo alguns dialetos alemães; estudei a gramática do húngaro, do árabe, do sânscrito, do lituânio, do polonês, do tupi, do hebraico, do japonês, do tcheco, do finlandês, do dinamarquês; bisbilhotei um pouco a respeito de outras. Mas tudo mal. E acho que estudar o espírito e o mecanismo de outras línguas ajuda muito à compreensão mais profunda do idioma nacional. Principalmente, porém, estudando-se por divertimento, gosto e distração.

Não satisfeito com isso, e talvez por compreender profundamente a arquitetura das palavras segundo a lógica de vários povos, dava-se ao luxo de recuperar palavras esquecidas do nosso idioma e de criar neologismos, como o instigante nome Môimechego, de um personagem do conto "Cara de bronze", no qual ele brinca com significantes da palavra eu em diferentes línguas: MOI-ME-ICH-EGO (francês, português, alemão e grego).

O escritor era fascinado pelo sentido primitivo das palavras, sentido este esgarçado ou banalizado pelo uso constante. Em correspondência com o tradutor alemão Günter Lorenz, comentou a etimologia do próprio nome: João Guimarães Rosa, "Weihs Mahr" = cavaleiro combatente ou cavalo de combate, passando a "Wimara" ou "Guimara", forma primitiva de Guimarães. Por isso se autodenominou "o Cavaleiro da Rosa do Burgo do Coração", referindo-se à terra natal, Cordisburgo, então ligada a Curvelo, na região central de Minas Gerais. O termo Cavaleiro da Rosa remete ao movimento esotérico Rosa Cruz e ao grau 18 da Maçonaria. O número em questão simboliza o indivíduo diante do infinito. Infinito é o oito deitado, símbolo que se fez 
presente nas ilustrações originais de Grande sertão: veredas por sugestão do próprio autor ao ilustrador Poty.

Dessa forma, seus personagens têm nomes que não foram dados aleatoriamente. Riobaldo lembra rio + aquele que governa, enquanto o nome Hermógenes significa filho de Hermes, 0 mensageiro de Zeus. Esse personagem lembra o Exu, mensageiro dos orixás, que, assim como os anjos católicos, se coloca acima do bem e do mal, como mero instrumento da vontade divina. Consuelo Albergaria, no excepcional estudo Bruxo da linguagem no Grande sertão, destaca a proximidade da obra com a mitologia, mas prefere associar o antagonista ao símbolo alquímico do mercúrio, elemento químico cujas propriedades derretem do ouro ao ferro.

Por seus nomes e características, os personagens rosianos dão margem a diversas leituras. O mais intrigante de todos talvez seja Diadorim (que significa "dada por Deus"). No livro O mundo movente de Guimarães Rosa, José Carlos Garbuglio enumera suas variantes para "traduzir" os significados: Dia + doron ou através + dádiva, dom, o que não exclui a possibilidade de outras significações, tais como di (dois) + adorar, ou o duplo adorado; ou ainda diá (através) + dor + in ou por intermédio da dor, do sofrimento. Por outro lado, diá é também a primeira sílaba de diabo, ou ainda dia + dor + in (sufixo indeterminante de gênero e, portanto, índice da natureza indefinida do personagem) e assim por diante.

Ao pé da letra, a palavra diabo significa aquele que é dois, o número da confusão, pois tanto somado quanto multiplicado por si mesmo resulta sempre no número quatro. Diadorim também se chama Reinaldo (aquele que governa com o conselho), nome que esconde a verdadeira identidade de Maria Deodorina da Fé Bettancourt Marins, filha de Joca Ramiro. Trata-se, portanto, de personagem andrógina.

Depois dos desenhos que Poty realizou sob a orientação do autor, a primeira pista mais evidente do esoterismo no romance Grande sertão: veredas refere-se ao fato de os personagens principais adotarem três nomes. Riobaldo não foge à regra. Admitido como companheiro pelos jagunços, ele é rebatizado Tatarana ou Lagarta de Fogo. Mais tarde, ao ser promovido a chefe (ou mestre) do bando, é renomeado Urutu Branco por sugestão de Zé Bebelo. Este, por sua vez, chama-se José Rebelo Adro Antunes.

Adro, destaca Albergaria em seu ensaio, "confirma a hipótese de ser zé Bebelo um chefe de terceira margem, o homem que chega ao limiar da chefia sem, no entanto, conseguir transpor seus umbrais e terminar definitivamente a sua luta". Para ela, que vê o São Francisco que divide o cenário do livro em duas 
margens (o Sertão e os Gerais $=0$ caos e o cosmos) como metáfora do rio da vida, Adro indica a posição profana de Zé Bebelo. Afinal, na igreja primitiva, adro era o espaço destinado aos não batizados ou pagãos. Em grego, a palavra "bebeloi" significa profano.

A ensaísta também chama a atenção para o pentagrama, estrela de cinco pontas simbolizada pelos cinco chefes de jagunços do romance: Joca Ramiro, Medeiro Vaz, Zé Bebelo, Hermógenes e Ricardão. Os dois últimos são os traidores (ou Judas) e, portanto, simbolizam a desarmonia, a divisão e o mal. Segundo - Dicionário ilustrado de símbolos, de Hans Biedermann, "em geometria, o pentagrama é o pentágono regular estrelado. Como a estrela de cinco pontas pode ser construída por uma única linha fechada entrelaçada, os pitagóricos (seguidores de Pitágoras) atribuíram-lhe um significado místico de perfeição, equilíbrio entre corpo e alma. Também recebeu nomes pejorativos, como pé de incubo, pegada da bruxa etc."

"Nas seitas gnóstico-maniqueístas, cujo número sagrado era cinco, porque conheciam cinco elementos (luz, ar, vento, fogo e água), o pentagrama adquiriu um significado simbólico importante, o que influenciaria outras seitas e ordens iniciáticas." Trata-se, no entanto, de um símbolo de dúbio significado. Com uma ponta para cima, representa o homem em equilíbrio ou o próprio bem, representado pelo Homem Vitruviano de Leonardo Da Vinci. Se uma ponta está para baixo, corresponderá à barbicha do bode, sendo que as duas pontas para o alto assumem a semelhança dos chifres de Belzebu (Senhor das Moscas), trazendo confusão e desordem. Baphomet, o ídolo com cabeça de bode supostamente adorado pela Ordem dos Cavaleiros Templários, tem um pentagrama na testa. Convém lembrar que os romances de cavalaria da Idade Média influenciaram sobremaneira a construção de Grande sertão: veredas, com destaque para Carlos Magno e os doze pares de França.

Na Maçonaria, a estrela flamejante é o símbolo do companheiro (segundo degrau da escada, ou segundo grau da escala iniciática: companheiro é aquele com quem se divide o pão). Ela tem cinco pontas, sendo também conhecida como selo de Davi, símbolo pitagórico e ainda pentagrama de Agripa, nos rituais de magia. Já o hexagrama, estrela de seis pontas que no Grande sertão: veredas será formada com a ascensão de Riobaldo ao status de chefe, corresponde ao grau de mestre, sendo conhecida como Signo de Salomão. A esse rei é atribuída a construção do templo de Jerusalém, onde teria surgido a ordem maçônica (maçom = pedreiro).

Existem, portanto, muitas leituras da obra rosiana que apontam sua relação com diferentes tradições, escolas filosóficas e/ou 
ordens iniciáticas. Consuelo Albergaria foi uma das primeiras estudiosas a olhar todos os ângulos dessa questão com visão caleidoscópica e holística da obra. No prefácio de Bruxo da linguagem no Grande sertão, Benedito Nunes afirma que ela recorre às doutrinas do Corpus Hermeticum e dos Mistérios da Antigüidade, às concepções gnóstico-cabalísticas, à Astrologia, à Alquimia, ao Taoísmo e ao repertório do Bramanismo, do Budismo e do Hinduísmo. "Consuelo nos mostra que essas fontes abastecem a metafísica da linguagem de Guimarães Rosa", ressalta o crítico.

A ensaísta também analisou o significado do nome Otacília quanto às duas primeiras sílabas. "Parece-nos pertinente a idéia de que se trata simplesmente de um anagrama do Tao, sem maiores complicações", afirma, lembrando que o Tao tanto pode se referir ao livro fundamental do Taoísmo, o Tao-Té-Ching de Lao Tsé, como também pode ser compreendido como doutrina filosófica definida. Guimarães Rosa gostava da grafia de "sertão" sem o til, na capa da tradução alemã, que resultou em "sertao" ou "ser Tao".

Vale também citar o esforço de outros estudiosos para decifrar - enigma rosiano. No livro João Guimarães Rosa: metafísica do Grande sertão, Francis Utéza afirma que "o interesse que Guimarães Rosa dava à metafísica é comprovado, em primeiro lugar, pelo seu engajamento maçônico, que remontava provavelmente à sua estada em Barbacena, em 1934, como deixa entrever a alusão feita no discurso de posse na Academia Brasileira de Letras: Barbacena, o nosso lugar geométrico."

Utéza aponta várias "evidências" da iniciação maçônica do escritor, como aquela parte na qual Riobaldo afirma que Deus é paciência: "Até as pedras do fundo, uma dá na outra, vão-se arredondinhando lisas, que o riachinho rola". Esse trecho faz alusão à pedra bruta que deve ser trabalhada pelo aprendiz maçom. No entanto, uma recente consulta às lojas maçônicas de Barbacena não revelou evidência de que o autor tenha sido iniciado naquela cidade. Apesar disso, o escritor maçom Manoel Lobato lembra que, ao conhecer Guimarães Rosa, no início dos anos 60, trocou com ele palavras e sinais da ordem.

Outro que escreveu sobre as ligações do autor com a Maçonaria é o poeta Hugo Pontes. No ensaio Guimarães Rosa, uma leitura mística, ele chama a atenção para o fato de as palavras Grande e Sertão começarem com letras sagradas: G, de Grande Arquiteto do Universo, Geômetra ou God; e $S$ de sabedoria, saúde e segurança, palavras proferidas durante o ritual chamado "cadeia de união", que geralmente encerra as reuniões maçônicas. Pontes também analisa o conto "O recado do morro" sob o prisma da astrologia, ligando nomes de personagens e 
fazendas a corpos celestes. E ele não é o único a se basear no Zodíaco para tentar desvendar o "recado" da obra em questão.

Já a professora Sílvia Meneses-Leroy, que hoje leciona em Londres, é autora do ensaio A cabala do sertão em Grande sertão: veredas que aponta elementos cabalísticos na obra do autor. O mesmo faz o médico e psicólogo José Maria Martins, com relação à Alquimia, no ensaio Guimarães Rosa: o alquimista do coração. E assim, meio século depois de sua primeira publicação, Grande sertão: veredas continua sendo uma obra seminal e instigante, que permite diversas leituras sob os mais diferentes prismas da compreensão humana.

No aspecto místico da obra, a palavra final é do próprio Guimarães Rosa: "Todos os meus livros são simples tentativas de rodear e devassar um pouquinho o mistério cósmico, esta coisa movente, impossível, perturbante, rebelde a qualquer lógica, que é a chamada 'realidade', que é a gente mesmo, o mundo, a vida". Para ele, "o idioma é a única porta para o infinito". Sobre o lado mágico da existência, dizia: "Minha vida sempre e cedo se teceu de sutil gênero de fatos. Sonhos premonitórios, telepatia, intuições, séries encadeadas fortuitas, toda a sorte de avisos e pressentimentos... Sou um contemplativo fascinado pelo Grande Mistério". Sobre sua obraprima, confessou no prefácio "Sobre a escova e a dúvida", em Tutaméia: "Quanto ao Grande sertão: veredas, forte coisa e comprida demais seria tentar fazer crer que foi ditado, sustentado e protegido - por forças ou corrente muito estranhas".

\section{Resumen}

En la novela Grande sertão: veredas, considerado el libro más importante publicado en Brasil, el escritor centenario Guimarães Rosa aborda con sutileza e inteligencia temas y símbolos relacionados con el conocimiento iniciático universal. Hombre místico confeso, el escritor nacido en Cordisburgo, Minas Gerais, instiga lectores e investigadores a estudiar su obra bajo el punto de vista de varias corrientes del pensamiento esotérico.

Palabras clave: Grande sertão: veredas, Guimarães Rosa, pensamiento esotérico. 